\section{Lidija Šajn}

Osnovna šola Louisa Adamiča

Grosuplje

lidija.sajn@oslag.si

\section{Ritem in ples - podpora pri učenju in razvoju}

Ritem je povezan s celostnim razvojem otroka, ustvarja svojevrsten red in ohranja notranjo disciplino. V otroku ustvarja trden in nujen občutek varnosti, kar kasneje vpliva na oblikovanje volje, čutenja in mišljenja. V prispevku bom predstavila nekaj ritmičnih dejavnosti, ki sem jih ob glasbi in plesu izvajala po pouku, v kombiniranem oddelku podaljšanega bivanja, in sicer v oddelkih učencev od 1. do 5. razreda, ki so tako z vedenjskimi vzorci kot učnim primanjkljajem nakazovali potrebo po vsem zgoraj omenjenem - skupno je bilo 22 starostno in razvojno različnih otrok, a prav vsak z željo po gibanju. Odločila sem se, da njihovo ustvarjalnost in radovednost povežem z glasbo, zvokom, gibom in s plesom. Prvošolcem smo $\checkmark$ ritmu pomagali zlogovati besede, drugošolci so se z gibanjem naučili deklamacijo, tretješolci so $v$ ritmu urili poštevanko, četrtošolci so ples potrebovali za motivacijo in razvedrilo, petošolca pa sta se z glasbo in s plesom lažje sprostila, prepustila in odprla. Menim, da plesne dejavnosti premalo vključujemo v šolski prostor, saj so mnogi učitelji prepričani, da nimajo ustreznega znanja, talenta in samozavesti za izvajanje plesnih dejavnosti. Vendar plesati ne pomeni zgolj učiti koreografij - plesati pomeni odpreti srce. Odprto srce pa je temelj za celovit otrokov razvoj.

Ključne besede: podaljšano bivanje, ritem, ples, vrstniško učenje, celostni razvoj

\section{Rhythm and Dancing - the Learning and Development Aid}

Rhythm is connected with complete child development, it creates a certain order and preserves inner discipline. It gives the child a firm and crucial feeling of safety that later on impacts the formation of will, sentience and thinking. This article presents some of the rhythmical activities that were carried out with music and dancing in the afterschool combined class. This was a class of first- to fifthgraders who indicated the need for all of the above, both with behavioural patterns as well as learning disabilities. There were 22 children of different ages and at different development stages, but each and every one of them with an urge to move. I decided to link their creativity and curiosity with music, sound, movement and dancing. We helped our first-graders syllabicate words, second-graders learned a declamation while moving, third-graders practiced the multiplication tables in rhythm, dancing motivated the fourth-graders and cheered them up, and the two fifth-graders found it easier to relax, indulge in and open up to music and dancing. I believe that dancing activities are not included enough in the school environment, as many teachers believe they do not have the sufficient knowledge, talent and, last but not least, self-confidence to engage in dancing activities. But dancing does not mean merely teaching choreographies. Dancing means opening up one's heart. And an open heart is the foundation for complete child development.

Key words: afterschool care, rhythm, dancing, peer learning, complete child development 